\title{
Bioactivity and pharmacological potential of Trianthema portulacastrum L. (Angiosperms: Aizoaceae): An overview
}

\author{
Anand Prakash $^{1}$, Pracheta $^{1} \&$ Vinay Sharma ${ }^{2 *}$ \\ ${ }^{1}$ Department of Bioscience and Biotechnology, Banasthali University, Rajasthan, India \\ ${ }^{2}$ Amity Institute of Biotechnology, Amity University Rajasthan, Jaipur, Rajasthan, 303002, India
}

\section{Article history}

Received: 28 November 2019 Accepted: 29 December 2019

Published: 31 December 2019

\section{Publisher}

Horizon e-Publishing Group

*Correspondence
Vinay Sharma
$\square$ vinaysharma30@yahoo.co.uk

\begin{abstract}
Trianthema portulacastrum L. (Biskhapra/ Horse purslane) is widely found in tropical and subtropical countries of the world. This weed automatically spread in cultivated fields. From the ancient time it is used for curative purposes. The plant pertains wide range of applicability and henceforth used as an Ayurvedic herb. The decoction of this herb is utilized as a vermifuge, antidote prepared from that helps in treating alcohol poisoning and leaves cure the wound. In the era of phytomedicines lot of work has been done related to its morphology, ethno-pharmacology, medicinal uses, phyto-chemistry and pharmacological properties. Various pharmacological properties like antimicrobial properties, analgesic, anti-inflammatory, anti-diabetic, antihyperglycemic, hepato-protective activity makes this plant very renowned amongst researchers as they utilized it somewhat like a panacea. Different parts of plants are utilized for the therapeutic purposes and extract prepared in different solvents used in the treatment of various disorders. In this review, an attempt has been made to provide all inclusive information of this plant about its bioactive compounds and their pharmacologoical importance.
\end{abstract}

Keywords: Aizoceae; Ethnopharmacology; Morphology; Phytochemistry; Trianthema.

Citation: Prakash A, Pracheta, Sharma V. Bioactivity and pharmacological potential of Trianthema portulacastrum L. (Angiosperms: Aizoaceae): An overview. Plant Science Today 2019;6(sp1):590-599. https://doi.org/10.14719/pst.2019.6.sp1.678

Copyright: (c) Prakash et. al. (2019). This is an open-access article distributed under the terms of the Creative Commons Attribution License, which permits unrestricted use, distribution, and reproduction in any medium, provided the original author and source are credited (https://creativecommons.org/licenses/by/4.0/).

Indexing: Plant Science Today is covered by Scopus, Web of Science, BIOSIS Previews, ESCI, CAS, AGRIS, UGC-CARE, CABI, Google Scholar, etc. Full list at http://www.plantsciencetoday.online

\section{Introduction}

Trianthema portulacastrum L. (TP) is one of the most important members of Aizoaceae family (1). Other than this, 20 more species are reported from the similar genus Trianthema, which is an annual or perennial plant and various researches reported about the therapeutic potential of this species. Various parts of this plant are used for the isolation of drugs and bioactive compounds (2). $T$. portulacastrum is a flowering plant commonly known as Horse purslane, Biskhapra and Giant pigweed (3). It is broadly distributed in tropical countries and is native to continents Africa, South and North America Southeast Asia. This review shows the evaluation of occurrence, morphology, ethnopharmocology, ecological, biodiversity, phytochemistry, medicinal uses, toxicity and pharmacological activities about $T$. portulacastrum. The Broad classification is tabulated in Table 1 (4). 
Table 1. Taxonomical Classification $(3,23)$

\begin{tabular}{ll} 
Domain & : Eukaryota \\
\hline Kingdom & : Plantae (Plants) \\
\hline Sub-kingdom & : Tracheobionta (Vascular plants) \\
\hline Division & $:$ Magnoliophyta (Flowering plants) \\
\hline Superdivision & $:$ Spermatophyta (Seed plants) \\
\hline Class & $:$ Magnoliopsida (Dicotyledons) \\
\hline Subclass & $:$ Caryophyllidae \\
\hline Order & $:$ Caryophyllales (Herbaceous and fleshy) \\
\hline Family & $:$ Aizoaceae (Fig-marigold family) \\
\hline Genus & $:$ Trianthema L. \\
\hline Species & $:$ Trianthema portulacastrum L. \\
\hline
\end{tabular}

\section{Distribution and occurrence}

T. portulacastrum is an exotic weed, native to tropical America but geographically occurring at most of the tropical, subtropical habitats, generally mung bean up to $60 \%$ and significant losses in soybean, maize and peanut (9).

\section{Vernacular names of the plant}

T. portulacastrum L., commonly known as black pigweed, gaint pigweed, itcit, gudbur, hogweed, desert purslane, horse purslane and lowland purslane. Apart from these common names, TP is globally utilized for its broad range of applications. It is known to people of distinct area by different regional names which is mentioned in Table 2 (10, 11).

\section{Morphology}

T. portulacastrum is the prostrate herb (Fig. 2) grows up to an average height of $40 \mathrm{~cm}$, it is pubescent, diffuse, prostrate, profusely branched species developed in mats or clump with stems and propagation occurs very rapidly on cutting (12). Leaves are of $1.5-2.5 \mathrm{~cm}$, stem is green in color, ascended, hispid, cylindrical, rounded, hairy and fleshy. Mature stem comprises of five successive

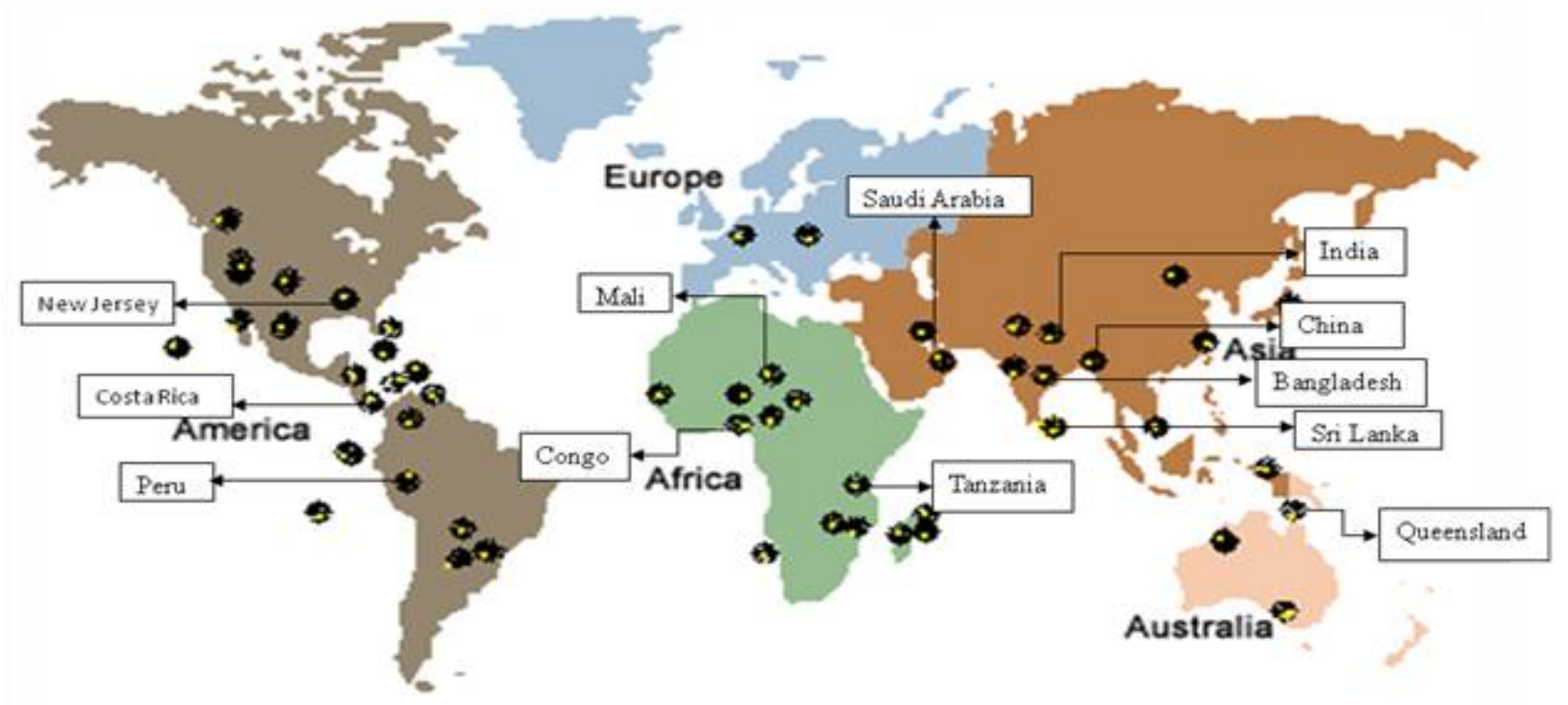

Fig. 1. Map showing distribution of TP all across the world.

distributed in Saudi Arabia, Bangladesh, Sri Lanka, Africa China, Egypt, Uganda, Ghana, Mali, Congo, New Jersey, Nevada, Utah, Virginia, Costa Rica, Peru, Chile as shown in Fig. $1(5,6)$. In India Biskhapra is naturalized throughout the cultivated fields, river beds, waste ground especially in the states of central and northern zone in which areas of Delhi, Rajasthan, Punjab and Uttar Pradesh. It thrives better in saline soil than that of alkaline soil (7). It is very common and easily visible in agricultural and vegetable crops such as pigeon pea, mung bean, cotton, pearl millete, sugarcane, soybean, onion, potato, maize, mustard, directseeded rice, tomato, oilseed, pulses and horticulture crops in India, Pakistan and Sri Lanka (8). This weed is reported to be strong competitor and reducing the yield by negative allelopathy in

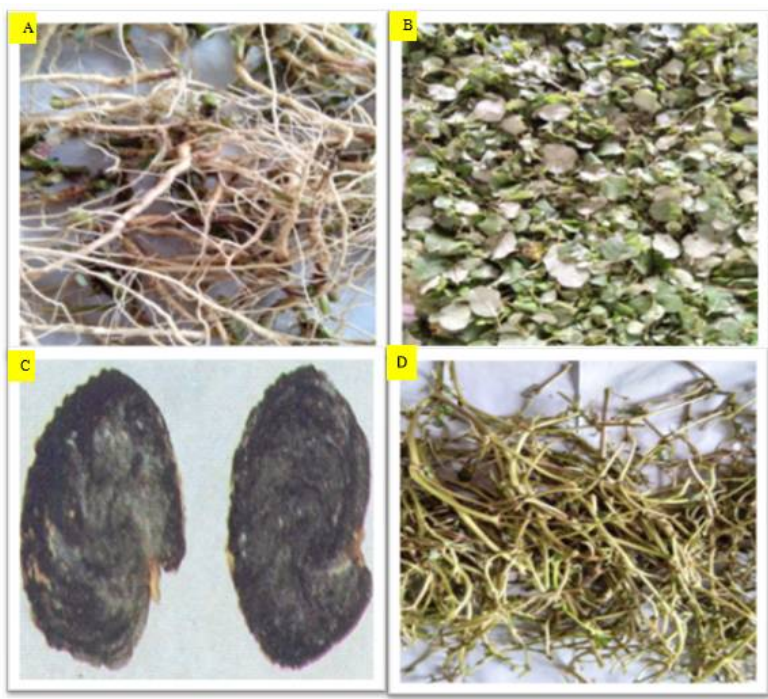

Fig. 2. T. potulacastrum L. (A. Root, B. Leaf, C. Seed, D. Stem). 
rings of cambium having fusiform cells, devoid of xylem rays and only consist of tracheids, vessels and fibers which help in transportation of water (13). Leaves are simple, fleshy, entire, broad, opposite, uneven, ovate-ovate, petiole dilated enclosing the stem, single mid-rib, dorsiventral, having two-layered palisade tissue, pinnately veined, green in colour and $2 \mathrm{~cm}$ long, $3 \mathrm{~cm}$ wide attached to the plant via $1 \mathrm{~cm}$ short petioles (14). It bears pink or purple and rarely whitish bisexual flowers and 1-3 in number. Flowering season of $T$. portulacastrum is approximately for five months which is from June to October, they bloom generally in morning hours and they are small in size with horn-like appendages with stipules and have green bracts generally fused with leaf bases with white sepals. Root is greenish-yellow from outside and is white in color from inside (15).

Table 2. Vernacular Names $(3,57)$

\begin{tabular}{ll}
\hline \multicolumn{1}{c}{ Language } & \multicolumn{1}{c}{ Local name } \\
\hline Arabic & Zaleya Pentandra, Hamd Qooqi \\
\hline Bengali & Godabani, Sabuni, Kulphasag, Swet punarnova \\
\hline Chinese & Jia Hai Machi \\
\hline English & $\begin{array}{l}\text { Giant pigweed, Desert Horse purslane, } \\
\text { Carpetweed }\end{array}$ \\
\hline Indonesia & Subang- subang \\
\hline Kannada & Muchchugoni, Pasalaesoppu, Sihi Punarnava \\
\hline Hindi & $\begin{array}{l}\text { Sabuni, Svetsabuni, Salsabuni,Vishakhapara, } \\
\text { Saphed Punamava }\end{array}$ \\
\hline Malayalam & $\begin{array}{l}\text { Tavilama, Talutama, Sharunnau, Pasalikeera, } \\
\text { Thazhuthama, Jamizhama }\end{array}$ \\
\hline Marathi & Pundhari-ghentuli, Pundharighetntuli \\
\hline Nepali & Setopunarnava \\
\hline Oriya & Dewasapt \\
\hline Punjabi & Biskhapra, Itsit, Sanaya \\
\hline Sanskrit & $\begin{array}{l}\text { Dhanapatra, Chiratika, Upothaki, Vishakha } \\
\text { Shvetamula, Dirghapatrika }\end{array}$ \\
\hline Sindhu & Sweta puruni, Luduru sas \\
\hline Spanish & Verdolaga \\
\hline Tamil & Sharunnai, Charu velai, Shavalai, Shaaranaj, \\
\hline Telugu & Mukuruttai \\
\hline Thai & Phelijeru, Ambatimadu, Galijenu, Atikamamidi \\
\hline Urdu & Narma, Biskhapra \\
\hline Unani & Lotoos Aghryoos \\
\hline Vietnamese & Sam bien, Cotam khoi, Rau sam gia \\
\hline
\end{tabular}

\section{Ethnopharmacology}

T. portulacastrum is popularly used throughout the globe due to its pharmacological activities against many disorders or diseases. Leaf extract of plant possesses antioxidant properties and act as poultice which is useful in the healing of wound (16), curing the chronic pain of osteoarthritis disease and its diuretic action help in curing edema (17), jaundice, strangury and also used to treat ascites and beriberi (18). Asthma and alcohol poisoning are cured by using decoction of leaves which carry antihelminthic properties, help in curing heart diseases, piles and also used as a vermifuge (19). Dried leaves used in treatment of Gonorrhea. Roots are abortifacient in high concentration whereas in optimum concentration its decoction used as an emmenagogue, it also cure liver obstruction, eye inflammation, asthma and relieve from constipation. Leaves of plant are used with soups and vegetables in African countries like Tanzania and Ghana (21).

\section{Phytochemistry}

Screening method help in determination of number of remarkable phytochemicals like alkaloid, carbohydrates, flavonoid, phenolic compounds, steroid and terpenoid (22), Photoecydosone in different parts of plant $T$. portulacastrum $\mathrm{L}$. which is used for various therapeutic and medicinal purposes (2). This plant is also a rich source of organic and inorganic components such as calcium $(\mathrm{Ca})$, magnesium $(\mathrm{Mg})$, nitrogen $(\mathrm{N})$, Iron $(\mathrm{Fe})$, Zinc(Zn), phosphorus(P), ascorbic acid (Vitamin C) and nicotinic acid (Vitamin B) (24) and this species comprised of excellent amount of fiber along with other nutrients which make it useful for animals as a food in the form of fodder while other species of genus Trianthema are rich in fats. Most of these species phosphorus and iron present in abundance whereas calcium is present in low percentage. The mineral profile of TP is tabulated in Table 3.

Table 3. Mineral profile of T. portulacastrum L.

\begin{tabular}{lcc}
\hline \multicolumn{1}{c}{ Content } & Quantity present & References \\
\hline Protein & $21.50 \%$ & $(52,53)$ \\
\hline Neutral Lipid & $95.2 \%$ & $(54)$ \\
\hline Polar Lipid & $4.80 \%$ & $(54)$ \\
\hline Crude Fibre & $43 \%$ & $(54)$ \\
\hline Carbohydrate & $30.20 \%$ & $(52)$ \\
\hline Hydrocarbons & $0.30 \%$ & $(54)$ \\
\hline Vitamin A & $0.081 \mathrm{mg} / 100 \mathrm{gm}$ & $(54)$ \\
\hline Vitamin C & $0.202 \mathrm{mg} / 100 \mathrm{gm}$ & $(54)$ \\
\hline Carotene & $2.3 \mathrm{mg} / 100 \mathrm{gm}$ & $(53)$ \\
\hline Calcium & $52 \mathrm{mg}$ & $(55)$ \\
\hline Chromium & $0.200 \mathrm{mg}$ & $(56)$ \\
\hline Copper & $8 \mathrm{ppm}$ & $(52)$ \\
\hline Iron & $6.44 \mathrm{mg} / \mathrm{kg}$ & $(55)$ \\
\hline Magnesium & $153 \mathrm{mg}$ & $(56)$ \\
\hline Manganese & $40 \mathrm{mg} / \mathrm{kg}$ & $(55)$ \\
\hline Nickel & $0.03 \mathrm{mg} / \mathrm{gm}$ & $(54)$ \\
\hline Phosphorus & $22 \mathrm{mg}$ & $(56)$ \\
\hline Potassium & $51.6 \mathrm{mg} / \mathrm{gm}$ & $(54)$ \\
\hline Sodium & $44 \mathrm{mg} / \mathrm{gm}$ & $(54)$ \\
\hline Zinc & $30 \mathrm{ppm}$ & $(54)$ \\
\hline
\end{tabular}

Phytochemical screening by using the methanol, chloroform and water extract helped in the determination of photochemicals which are acetylaleuritolic acid (25), dimethoxycinnamic acid, 5,7-dihydroxy-6-8-dimethylchromone (Leptorumol), dihydroxy-7-methoxy-6-8-dimethyl flavones, 5-hydroxy-2-methoxybenzaldehyde, pmethoxybenzoic acid, Quercetin and plays a major role in drug development (Fig. 3).

$T$. portulacastrum flower consists of alkaloid punarnavine (26). These phytochemicals are reported in the aerial parts of the plant (27). Presence of dichloromethane in the extract of 


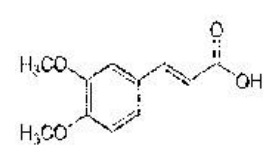

3-Acetylaleuritolic acid

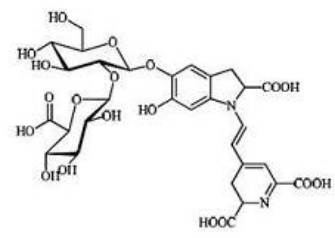

$\beta$-cyanin,<smiles>O=C(O)/C=C/c1ccc(O)c(O)c1</smiles>

Caeffic acid

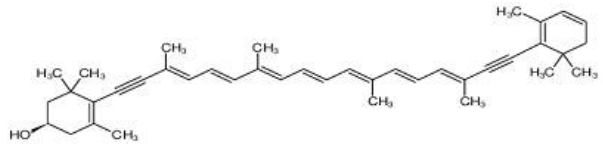

$\beta$-carotene

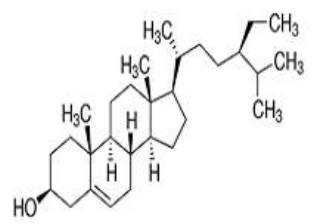

$\beta$-sitosterol

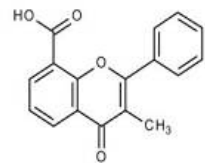

C-methylflavone

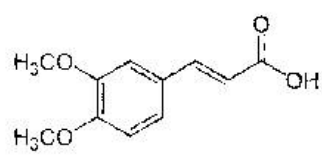

3,4-dimethoxy cinnamic acid

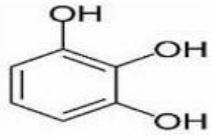

Pyrogallol

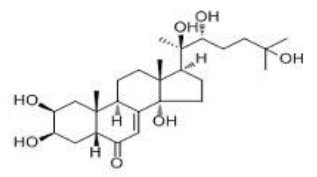

Ecdysterone

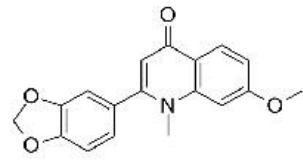

Punarnavine

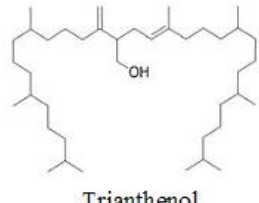

Trianthenol<smiles>COc1cc(C(=O)O)ccc1O</smiles>

Vannilic acid<smiles>COc1cc(/C=C/C(=O)O)ccc1O</smiles>

Ferulic acid

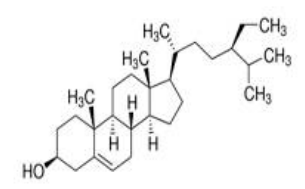

Sitosterol

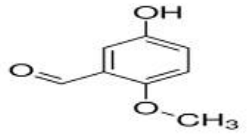

5-Hydroxy-2-methoxybenzaldehyde<smiles>Cc1c(O)c(C)c2occc(=O)c2c1O</smiles>

Leptorumol<smiles>O=c1c(O)c(-c2ccc(O)c(O)c2)oc2cc(O)cc(O)c12</smiles>

Quercitin

Fig. 3. Structures of various phytochemicals present in T. portulacastrum L.

dried leaf reported new flavonoids, 5,2'-dihydroxy7-methoxy-6,8-dimethyl flavones

5,7-dihydroxy-6,8 methylflavone), 5,7-dihydroxy-6,8dimethylchromone (leptorumol) and its structure
is been reported by X-ray analysis. Red color pigment $\beta$-Cyanin is one of the prominent flavanoid of $T$. portulacastrum. Qualitative analysis by chromatographic separation of plant extract gave mixtures of sterols which are stigma sterol, $\beta$-sitosterol and their $\beta$-glucopyranosides. An important tetraterpeniod named trianthenol with antifungal properties reported in chloroform extract (28).

\section{Pharmacological activities}

$T$. portulacastrum is a medicinal weed which shows many recognizable pharmacological activities like antimicrobial, antiparasitic, antiinflammatory, antioxidant, diuretic, antihyperglycemic, antipyretic and cancerpreventive therapeutic properties that are been depicted in (Fig. 4). It is also reported for combating other disorders such as gastrointestinal, jaundice, edema, hormonal, cardiovascular and skin-related diseases (29).

\section{Analgesic activity}

Evaluation of ethanolic extract of plant $T$. portulacastrum was done and outcome it showed its antinociceptive activity in mice. The effect of analgesic activity was checked by introducing the doses for central and peripheral analgesic like morphine, aspirin and streptomycin. Which was found to be inactivate of pain relief, the effect of plant extract showed close value to that of aspirin which seems to help in blocking of writhing response gave value of $\mathrm{P}$ less than $0.005(\mathrm{P}<0.005)$ (30).

\section{Antifungal activity}

It was reported that horse purslane extract against $F$. chlamydosporum found to be very effective which causes leaf-spot disease in the plants. Besides, many reports admitted that the both chloroform extract of plant and well known phytochemical trianthenol (Tetraterpenoid) shows the antifungal activity (31).

\section{Anticarcinogenic activity}

The chloroform extract and ethanolic extracts of the plant showed reliable result in chemoprotective activity as clearly manifested in (Table 4). When in mice a potent carcinogen named, DENA (diethylnitrosoamine) was introduced that induced hepatocancer in a mice model and this chemical reduces the nodules size of rat's liver. The dose of plant extract which is been prepared in ethanol reviled the best result 
than that of chloroform, inhibiting cell proliferation and also suppressed the effect chemical DENA. It was effective in reducing carcinogenic activity up to $25 \%$ and acted as most which is been produced by injecting dose of streptozotocin-induced diabetic rats. Demonstration of antihyperglycemic activity by the extract is done by lowering down the glucose

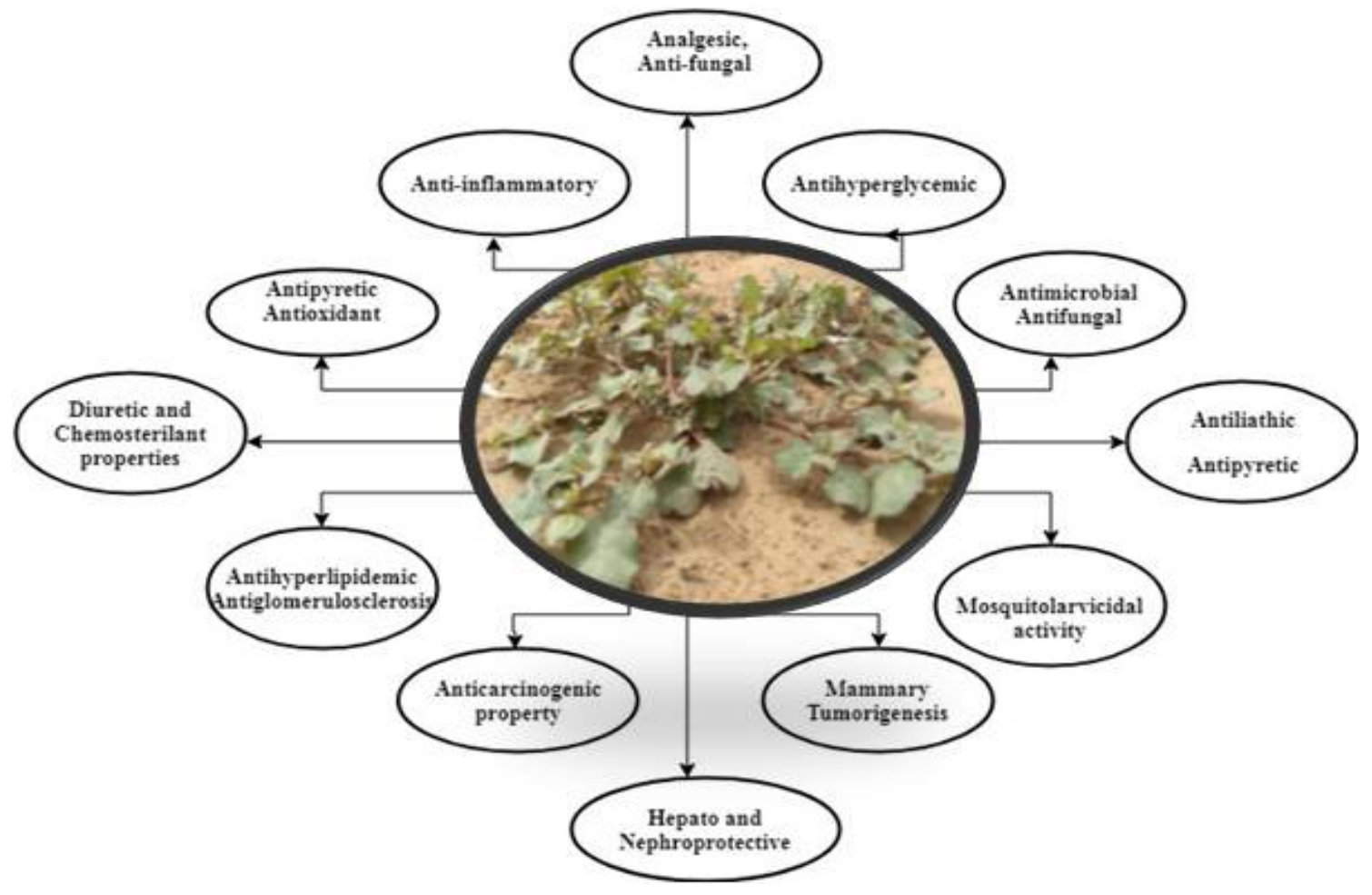

Fig. 4. Overview of pharmacological properties of TP.

active in inhibition of hepatic cancer (32).

\section{Antifertility activity}

T. portulacastrum has been well known for its antifertility properties because of the presence of phytochemical like steroid and ecdysterone that has been naturally present. Hence, it is employed as a contraceptive and abortifacient by some rural peoples and tribal communities of India. This tendency was studied in aqueous, chloroform and alcoholic extracts of plant, to exhibit antifertility activity. It was found that alcoholic, chloroform and aqueous extract perform 94\%, 73\% and 64\% abortifacient activity. From this, it was clearly depicted that alcoholic extract is most potential as antifertility agent (33).

\section{Antihyperlipidemic property}

When there is a rise in concentration of lipids such as phospholipids, cholesterol or triglycerides due to factors like fatty diet, intake of drugs and genetic defects causes hyperlipidemia (34). Against this hyperlipidemia, the methanolic extract of $T$. portulacastrum manifested antihyperlipidemic activity and hence used to develop hypolipidemic drugs from natural sources to prevent the individual from cardiovascular diseases (35).

Plant extract of $T$. portulacastrum significantly used to cure diabetes mellitus. Methanol extract of $T$. potulacastrum (METP) shows antihyperglycemic activity in diabetic rats level which is being monitored in diabetic rats (36).

\section{Antimicrobial properties}

Some reports depicted that $T$. portulacastrum possessed antimicrobial properties and found to be effective against both gram positive and gramnegative bacteria, fungi and helminthes because of the presence of photochemical available in plant (37). Plant extract prepared from roots showed antimicrobial property against bacteria Bacillus subtilis, Escherichia coli, Proteus vulgaris and Staphylococcus aureus. Phytochemical screening confirmed the presence of alkaloid, flavonoid, sterols and phenolic compounds in the plant. Further attribution to the research explored that fraction of flavonoid of plant $T$. portulacastrum performed better antimicrobial and antifungal propertied, based on zone of inhibition than that of phenolic and alkaloid fractions in the methanolic extract (38).

\section{Nephroprotective effects}

Nephroprotective effects has been studied in renal damaged mice against whom methanolic extract of $T$. portulacastrum pertained nephroprotective action because of its DPPH-free radical scavenging and antioxidant property. Renal damaged mice developed in an experimental model by Adriamycin in against which the extract improved the histopathological effects that was caused due to disease condition (39). 
Table 4. In vivo investigation of anti-carcinogenic property of plant T. portulacastrum.

\begin{tabular}{|c|c|c|c|c|c|c|c|c|c|c|}
\hline $\begin{array}{l}\text { Sl. } \\
\text { No. }\end{array}$ & $\begin{array}{c}\text { Plant } \\
\text { Extract }\end{array}$ & $\begin{array}{c}\text { Exp. } \\
\text { Model }\end{array}$ & $\begin{array}{c}\text { Disease } \\
\text { Targeted }\end{array}$ & $\begin{array}{c}\text { Toxic } \\
\text { control }\end{array}$ & Dose & Route & Duration & Investigation & Results & Ref. \\
\hline 1 & $\begin{array}{l}\text { Ethanolic } \\
\text { extract of } \\
\text { stem and } \\
\text { leaves }\end{array}$ & $\begin{array}{l}\text { Female } \\
\text { Sprague- } \\
\text { Dawley } \\
\text { rat }\end{array}$ & $\begin{array}{l}\text { Mammary } \\
\text { carcinogen } \\
\text { esis }\end{array}$ & $\begin{array}{l}\text { 7,12- } \\
\text { dimethylbe } \\
\text { nz(a)anthra } \\
\text { cene }\end{array}$ & $\begin{array}{l}50,100 \\
\text { and } 200 \\
\mathrm{mg} / \mathrm{kg}\end{array}$ & p.o. & 18 weeks & $\begin{array}{l}\text { Suppressed } \\
\text { proliferating cell } \\
\text { nuclear antigen } \\
\text { and cyclin D1 } \\
\text { expression, } \\
\text { induced } \\
\text { apoptosis }\end{array}$ & $\begin{array}{l}\text { Strong anti- } \\
\text { carcinogic } \\
\text { compounds }\end{array}$ & (54) \\
\hline 2 & $\begin{array}{l}\text { Chloroform } \\
\text { extract of } \\
\text { stem and } \\
\text { leaves }\end{array}$ & $\begin{array}{l}\text { Male rat } \\
\text { (Sprague- } \\
\text { Dawley) }\end{array}$ & $\begin{array}{l}\text { Hepatocar } \\
\text { cinogenesi } \\
\mathrm{s}\end{array}$ & $\begin{array}{l}\text { DENA- } \\
\text { initiated }\end{array}$ & $\begin{array}{l}100 \mathrm{mg} / \\
\mathrm{kg} / \mathrm{day}\end{array}$ & p.o. & $\begin{array}{l}4-20 \\
\text { weeks }\end{array}$ & $\begin{array}{l}\text { Decrease in } \\
\text { Nodule incidence } \\
\text { and multiplicity } \\
\text { as well as } \\
\text { decrease nodular } \\
\text { volume and area. } \\
\text { Reduced liver cell } \\
\text { foci/cm² and focal } \\
\text { area }\end{array}$ & $\begin{array}{l}\text { Ppotential of anti- } \\
\text { carcinogenic }\end{array}$ & (53) \\
\hline 3 & $\begin{array}{l}\text { Ethanolic } \\
\text { extract }\end{array}$ & $\begin{array}{l}\text { Wistar } \\
\text { albino } \\
\text { rats }\end{array}$ & $\begin{array}{l}\text { Breast } \\
\text { cancer }\end{array}$ & & $\begin{array}{l}50,100 \\
\text { and } 200 \\
\mathrm{mg} / \mathrm{kg} \\
\text { b.w }\end{array}$ & & 16 weeks & $\begin{array}{l}\text { TP suppressed } \\
\text { proliferating cell } \\
\text { nuclear antigen } \\
\text { and cyclinD1 } \\
\text { expression, } \\
\text { induced } \\
\text { apoptosis, down } \\
\text { regulated } \\
\text { antiapoptotic } \\
\text { protein Bcl-2 and } \\
\text { diminished the } \\
\text { expression of } \\
\text { nuclear and } \\
\text { cytosolic b- } \\
\text { catenin in } \\
\text { mammary } \\
\text { tumors }\end{array}$ & $\begin{array}{l}\text { Exerted } \\
\text { chemopreventive } \\
\text { effect in the } \\
\text { classical DMBA } \\
\text { model breast } \\
\text { cancer }\end{array}$ & (50) \\
\hline 4 & $\begin{array}{l}\text { Ethanolic } \\
\text { extract }\end{array}$ & $\begin{array}{l}\text { Wistar } \\
\text { albino } \\
\text { rats }\end{array}$ & $\begin{array}{l}\text { Mammary } \\
\text { carcinogen } \\
\text { esis }\end{array}$ & $\begin{array}{l}\text { 7,12- } \\
\text { Dimethylbe } \\
\text { nz(a)anthra } \\
\text { cene } \\
\text { (DMBA) }\end{array}$ & $\begin{array}{l}50,100 \\
\text { and } 200 \\
\mathrm{mg} / \mathrm{kg}\end{array}$ & & 16 weeks & $\begin{array}{l}\text { TP down } \\
\text { regulated the } \\
\text { expression of } \\
\text { cyclooxygenase-2 } \\
\text { and hsp 90, } \\
\text { blocked the } \\
\text { degradation of } \\
\text { inhibitory kappa } \\
\text { B-alpha }\end{array}$ & $\begin{array}{l}\text { Induced breast } \\
\text { neoplasia by anti- } \\
\text { inflammatory } \\
\text { mechanisms }\end{array}$ & (50) \\
\hline 5 & $\begin{array}{l}\text { Aqueous } \\
\text { ethanol and } \\
\text { choloroform } \\
\text { extract }\end{array}$ & $\begin{array}{l}\text { Male } \\
\text { Sprague } \\
\text { Dawley } \\
\text { rats }\end{array}$ & $\begin{array}{l}\text { Hepatocar } \\
\text { cinogenesi } \\
\mathrm{s}\end{array}$ & $\begin{array}{l}\text { Diethylnitro } \\
\text { soamine } \\
\text { (DENA) }\end{array}$ & $\begin{array}{l}100 \mathrm{mg} / \\
\mathrm{kg}\end{array}$ & p.o. & $\begin{array}{l}\text { Daily for } \\
22 \text { weeks }\end{array}$ & $\begin{array}{l}\text { TP increased } \\
\text { glutathione levels } \\
\text { and the levels of } \\
\text { Phase I } \\
\text { (cytochrome P- } \\
450 \\
\text { monooxygenase) } \\
\text { and Phase II } \\
\text { (UDPGT) } \\
\text { enzymes. } \\
\text { Decrease in lipid } \\
\text { peroxidation }\end{array}$ & $\begin{array}{l}\text { TP exerted as } \\
\text { strong } \\
\text { anticarcinogenic } \\
\text { compounds }\end{array}$ & (52) \\
\hline
\end{tabular}

\section{Chemosterilants/molting hormone activity}

T. portulacastrum contains well known phytoecdysteroids called Ecdysteroids. Ecdysterone and its analogs tend to stimulate protein synthesis in mammals as well as in arthropods and hence act as a chemosterilants (40). Larva of Musca domestica (housefly) selected as a model for the experiment to check molting hormone activity of plant in which abdomen of model is dipped in plant extract and responded by the formation of pupanum just by $0.01 \mu \mathrm{g}$ ecdysterone dose (41).

\section{Antipyretic activity}

The rise in body temperature that is more than $38.3{ }^{\circ} \mathrm{C}$ is known as pyrexia or fever, acute infection body respond against this alleviated temperature by releasing cyclo-oxygenase from prostaglandins (42). But this response doesn't go for prolonged or chronic infection recorded the antipyretic activity of $T$. portulacastrum. In his experiment, yeast-stable pyrexia was induced in rats against which antipyretic activity was shown by ethanol extract of $T$. portulacastrum (43). 


\section{Antioxidant properties}

Plant extract of $T$. portulacastrum is enriched with many antioxidant compounds out of which the major one is Gallic acid which is reported as $50 \mathrm{mg}$ in roots, $75 \mathrm{mg}$ in shoots and $98.09 \mathrm{mg}$ in leaves that is equivalents to per gram dry weight of plant (44). From the above statement it is clear that leaf extract of plant persist highest antioxidant properties over root and shoot. The ethanol extract of leaves was chosen for further investigation for the antioxidant properties and in rats it showed the relation with thioacetanamide, hepatotoxins and paracetamol. Reactive oxygen species, free radical and oxidative stress cause many degenerative diseases in an individual and also damage the body organs as well as genomic material. These oxidant species lowering the concentration of antioxidant enzyme like catalase (CAT), glutathione reductase (GSH-R), glutathione peroxidase (GPX), superoxide dismutase (SOD) and glutathione-S-transferase (GST) but after treatment with plant extract, enzymes attain the normal concentration in the experimental model and prevented from diseased condition (45).

\section{Diuretic Properties}

In India $T$. portulacastrum is commonly been used for ethnomedicinal purposes because of its diuretic activity. When diuretic activity of plant extract compared with standard diuretic that is furosamide than it gave $79 \%$ result in response to the plant dose of concentration $50 \mathrm{mg} / \mathrm{kg}$ and also produces kaliuretic and natiuretic effects (46). A similar investigation was done and reported in further investigations. Researchers are still far from mechanism but certainly it is due to the presence of phytochemicals in plant (43).

\section{Hepatoprotective effects}

Hepatotoxicity has been induced in albino rats by introducing familiar hepatotoxins thioacetamide and paracetamol in response to which ethanolic extract showed antihepatoprotective activity (47). The intake of higher amount of paracetamol promotes hepatic necrosis and also prescribed as an antipyretic and analgesic agent. Against these hepatotoxins $T$. portulacastrum stimulated regeneration of hepatic cells and also promoted detoxification (48).

\section{Antiglomerulosclerosis}

During glomerulosclerosis there is a rise in the level of creatinine and enzymes aspartate, transaminases and alanine. To overcome this, 100 and $200 \mathrm{mg} / \mathrm{kg}$ of methanolic extract of plant provided protection in experimental model rats against diet that induced glomeruloscelerosis. It also pertain protective property against hepatic damage, CCT ( $4 \%$ cholesterol, $1 \%$ cholic acid and $0.5 \%$ thiouracil) and antherosclerotic disease (49).

\section{Mosquito larvicidal activity}

Aqueous and acetone extract of plant $T$. portulacastrum persisted best larvicidal activity and $100 \%$ mortality rate has been found at third stage of instar larvae at different concentration of on different species of mosquitoes which includes Culex quinquefaciatus, Anopheles culcifacies, Anopheles stephensi and Aedes aegypti. On the basis of $\mathrm{LD}_{50}$ and $\mathrm{LD}_{90}$ values of larvae of different mosquitoes it was concluded that acetone extract pertained better larvicidal activity over crude aqueous extract of experimental plant (20).

\section{Mammary tumor genesis}

Breast tumor was developed upon introduction of 40,50 and $100 \mathrm{mg} / \mathrm{kg}$ concentration of 7, 12dimethylbenz (a) and anthracene (DMBA) in the mice by supplementing with diet. Ethanolic extract of $T$. portulacastrum reported to suppress the activity of DMBA which initiate tumorigenesis. It also helped in proliferating expression of cyclin D1, upregulated propoptotic protein Bax, downregulated antiapoptotic protein Bcl2 and induced apoptosis by regulating or changing the ratio of proteins $\mathrm{Bax}$ and $\mathrm{Bcl} 2$. It diminished the irregular and abnormal cell proliferation and canonical Wnt signaling pathways which showed oncostatic effects (50).

\section{Anti-inflammatory Properties}

Chloroform extract of $T$. portulacastrum induced anti-inflammatory effects and resist $58.36 \%$ of inflammation of rat paw edema assay induced on animal by carrageenans which release histamine and 5-hydroxy histamine initially and then kinin and prostaglandin in latter phase. Same as in dextran plant shows resistivity against inflammation which also induce paw edema as that of carrageenans but other than histamine, it is also mediated by serotonin which is inflammation mediators in nature and help to suppress inflammation. The anticancerous properties are also directly or indirectly linked with anti-inflammatory potential of plant. By lowering the inflammatory stress response inhibition of Chemical Dimethylbenzanthracene (DMBA) is done which induces the breast tumorogenesis (51).

\section{Antilithic activity}

Antiliathic activity inhibits the formation of kidney stones and help in getting rid its symptoms. When urolithiasis is experimentally induced in model it causes the formation of kidney stone which get cure on treating the animal with ethanolic extract of $T$. portulacastrum made from leaves (45).

\section{Conclusion}

Based on this review, it can be concluded that the distinct parts of plant $T$. portulacatrum employed 
to perform various functions. Detailed comparative physicochemical and phytochemical studies on different parts of $T$. portulacatrum reported and the data justified the applicability of this plant in traditional systems of medicine. Natural and herbal drugs are recognized as safe but can also lead to adverse reactions, therefore correct identification and adulteration can help to validate it as potential drug candidate. Different polyphnolics isolated from the extract prepared in different solvents which seems to persist number of pharmacological properties such as antimicrobial, analgesic, anti-inflammatory, antidiabetic, anti-hyperglycemic, hepato-protective activity and help in curing many disorders. This review is an effort to bring all the properties of this plant together that was reported at times. This report explored important therapeutical properties of this herb and its curative nature which converge the interest of researchers towards this plant. This study finally concludes that $T$. portulacastrum $\mathrm{L}$. is an unusual and unbelievable source with so much to offer the world of medicine.

\section{Conflict of interest}

All authors declared that they have no conflict of interest in the publication.

\section{Acknowledgements}

The authors are grateful to Prof. Aditya Shastri, Vice Chancellor, Banasthali Vidyapith for providing all necessary support. We acknowledge the Bioinformatics Center, Banasthali Vidyapith supported by DBT for providing computation support, and DST for providing networking and equipment support through the FIST and CURIE programs at the Department of Bioscience and Biotechnology. CESME, Banasthali Vidyapith, supported by MHRD, Government of India under the PMMMNMTT is acknowledged for organizing the symposium.

\section{References}

1. Yaqoob S, Sultana B, Mushtaq M. In vitro antioxidant activities of Trianthema portulacastrum L. Hydrolysates. Prev Nutr Food Sci. 2014;19(1):27-33. https://doi.org/10.3746/pnf.2014.19.1.027

2. Yamaki J, Venkata KC, Mandal A, Bhattacharyya P, Bishayee A. Health-promoting and disease-preventive potential of Trianthema portulacastrum Linn. (Gadabani)An Indian medicinal and dietary plant. J Integr Med. 2016;14(2):84-99.

https://doi.org/10.1016/S2095-4964(16)60247-9

3. Gaddeyya G, Kumar PR. A Comprehensive review on ethnobotany and photochemistry of a herbal weed Trianthema portulacastrum L. J Pharmacogn Phytochem. 2015;4(4):25-31.

4. Anreddy RNR, Porika M, Yellu NR, Devarakonda K. Hypoglycemic and hypolipidemic activities of Trianthema portucastrum Linn. Plants in normal and alloxan induced diabetic rats. Int J Pharmacol. 2010;6(2):129-33. https://doi.org/10.3923/ijp.2010.129.133

5. Ara A, Akram A, Ajmal M, Akhund S, Nayyar BG. Pharmacological, nutritional and allelopathic attributes of noxious weed, Trianthema portulacastrum L. (Horse purslane). Pure Appl Biol. 2015;4(3):340-52. http://dx.doi.org/10.19045/bspab.2015.43010

6. Holm LG, Pancho JV, Herberger JP. A geographical atlas of world weeds. New York, USA: John Wiley and Sons; 1979. pp. 391.

7. Kaur M, Aggarwal NK. Trianthema portulacastrum L.- the noxious weed and its control. Adv Plants Agric Res. 2017; 6(3):62-64.

8. Hazra D, Das TK, Yaduraju NT. Interference and economic threshold of horse purslane (Trianthema portulacastrum) in soybean cultivation in northern India. Weed Biol Manag. 2011;11(2):72-82. https://doi.org/10.1111/j.14456664.2011.00408.x

9. Saeed MK, Marwat B, Hassan G, Khan A, Khan IA Interference of horse purslane (Trianthema portulacastrum L.) with maize (Zea mays L.) at different densities. Pak J Bot. 2010;42:173-79.

10. Karim MS, Ashraf N, Kalam A, jahan N, Jafri MA, Ahmad G. Effects of Biskhapra (Trianthema portulacastrum Linn.) leaves extract in adriamycin induced nephritic syndrome. Int. J. Green Pharm. 2011;5(4):329-35. https://doi.org/10.4103/0973-8258.94357

11. Pande J, Kanakiya A, Padalia H, Chandra S Physicochemical, phytochemical and pharmacognostic evaluation of a halophytic Plant, Trianthema portulacastrum L. Int J Curr Microbiol App Sci. 2018;7(5):1486-502.

https://doi.org/10.20546/ijcmas.2018.705.175

12. Patil VS, Rajput KS, Malpathak NP. Comparartive study on morpho-anatomy of leaf, stem and root of Boerhaavia diffusa L. (Nyctaginaceae) and its adulterant plants. Brazialian Journal of Pharmaceutical Sciences. 2016;52(3): 433-42. https://doi.org/10.1590/S1984-82502016000300009

13. Prasad S. Pharmacognostical studies of Punarnava; stem and leaf characteristics of Boerhaavia diffusa Linn. and Trianthema portulacastrum Linn. Journal of American Pharmacist Association. 1948;37(3):103-15. https://doi.org/10.1002/jps.3030370306

14. Bruckmann C, Gerbaulet M, Hammer SA, Hansen B, Hartmann HE, Ihlenfeldt HD, et al. Illustrated Handbook of Succulent Plants: Aizoaceae AE. Springer Science and Business Media; 2001.

15. Hassan NS, Thiede J, Liede-Schumann S. Phylogentic analysis of Sesuvioideae (Aizoaceae) inferred from nrDNA internal transcribed spacer (ITS) sequences and morphological data. Plant Systematics and Evolution. 2005; 255: 121-43. https://doi.org/10.1007/s00606-005-0357-x

16. Umarani R, Selvaraj JA. Studies on the growth and yield of carpet weed (Trianthema portulacastrum) as influenced by soybean (Glycine max (L.) Merrill). Indian J Weed Sci. 1995; 27:209-10.

17. Rajput KS, Rao KS. Cambial anatomy and absence of rays in the stem of Boerhaavia species (Nyctaginaceae). Ann Bot Fennici https://www.jstor.org/stable/23726540 1998;35:131-35.

18. Rajput KS, Patil VS, Shah DG. Formation of successive cambia and stem anatomy of Sesuvium sesuvioides (Aizoaceae). Botanical J Linn Soc. 2008;158:548-55. https:// doi.org/10.1111/j.1095-8339.2008.00867.x

19. Lakshmi S, Prabhakaran KV, Mallikarjuna G, Gowthami A Antilithiatic activity of Trianthema portulacastrum L. and Gymnema sylvestre R. Br. against ethylene glycol induced urolithiasis. Int J Pharm Sci Rev Res. 2014;25(1):16-22. 
20. Singh AK, Raghubanshi AS, Singh JS. Medical ethnobotany of the tribals of Sonaghati of Sonbhadra district, Uttar Pradesh, Indian J Ethnopharmacol. 2002;81(1):31-41. https://doi.org/10.1016/s0378-8741(02)00028-4

21. Senthilkumar M, Gurumoorthi P, Janardhanan K. Some medicinal plants used by Irular, the tribal people of Marudhamalai hills, Coimbatore, Tamil Nadu. Natural Product Radiance. 2006;5(5):382-88. http://nopr.niscair.res.in/handle/123456789/8011

22. Sarkar A, Pradhan S, Mukhopadhyay I, Bose SK, Roy S, Chatterjee M. Inhibition of early DNA-damage and chromosomal aberrations by Trianthema portulacastrum L. in carbon tetrachloride-induced mouse liver damage. Cell Biology International. 1999;23(10):703-800. https://doi.org/10.1006/cbir.1999.0439

23. Shivhare MK, Singour PK, Chaurasiya PK, Pawar RS. Trianthema portulacastrum Linn. (bishkhapra). Pharmacognosy reviews. 2012;6(12):132-40.

24. Bharathidhasan S, Babu GNS, Balakrishnan V. In vitro Evaluation of the nutritive value of Trianthema portulacastrum as a source of fodder for ruminants. Mal J Nutr. 2007;13(2):179-87.

25. Nawaz HR, Malik A, Ali MS. Trianthenol: an antifungal tetraterpenoid from Trianthema portulacastrum (Aizoaceae). Phytochemistry. 2001;56(1):99-102. https://doi.org/10.1016/s0031-9422(00)00270-3

26. Kumar G, Banu GS, Pappa PV, Sundararajan M, Pandian MR. Hepatoprotective activity of Trianthema portulacastrum $\mathrm{L}$. against paracetamol and thioacetamide intoxication in albino rats. J Ethnopharmacol. 2004; 92(1):37-40. https://doi.org/10.1016/j.jep.2003.12.009

27. Khan N, Sultana A, Tahir N, Jamila N. Nutritional composition, vitamins, minerals and toxic heavy metals analysis of Trianthema portulacastrum L., a wild edible plant from Peshawar, Khyber Pakhtunkhwa. Pak Afr J Biotechnol. https://doi.org/10.5897/AJB2013.12972

28. Shyam Sunder A, Reddy ARN, Rajeshwar Y, Kiran G, Krishna Prasad D, Baburao B, et al. Protective effect of methanolic extract of Trianthema portulacastrum in atherosclerotic diet induced renal and hepatic changes in rats. Der Pharmacia Lettre. 2010;2(1):540-45.

29. Shivhare MK, Singour PK, Chaurasiya PK, Pawar RS. Trianthema portulacastrum Linn. (Bishkhapra). Pharmacognosy $\quad$ Review. 2012;6(12):132-40. https://doi.org/10.4103/0973-7847.99947

30. Umesh GW. Analgesis activity of ethanolic extract of the plant Trianthema portulacastrum in experimental model. J of Evolution of Med and Dent Sc. 2015;4(34):5867-71. https://doi.org/10.14260/jemds/2015/858

31. Aneja KR, Kumar V, Sharma C. Leaf-spot disease of Trianthema portulacastrum - a new record from world. J Innov Biol. 2014;1(2):112-16.

32. Bhattacharya S, Chatterjee M. Trianthema portulacastrum restores the antioxidant defense enzyme levels and hepatic biotransformation patterns in experimental rat hepatocarcinogenesis. Ital J biochem. 1998;47(4):225-32.

33. Kumar SS, Bama S, Kiruthiga N, Kumar RS, Sivakumar T and Dhanabal P. Investigation of analgesic activity of leaves part of the Trianthema portulacastrum L. in standard experimental animal models. Int J Green Pharm. 2007;1(1):39-41.

34. Harrison D, Griendling KK, Landmesser U, Hornig B, Drexler H. Role of oxidative stress in atherosclerosis. Am J Cardiol. 2003;91(3A):7A-11A. https://doi.org/10.1016/S0002-9149(02)03144-2

35. Lu YF, Lu SW. Influence of dietary fat saturation on lipid peroxidation of serum and low density lipoprotein in rats.
Nutr Res. 2002;22(4):463-72. https://doi.org/10.1016/S0271 5317(01)00404-3

36. Sunder AS, Rajyalakshmi G, Bharath A, Rajeshwar Y Antihyperglycemic activity of Trianthema portulacastrum plant in Streptozotocin induced diabetic rats. Pharmacology online. 2009;1:1006-11.

37. Obeidat M, Shatnawi M, Al-alawi M, Al-Zu 'bi E, Al-Dmoor $\mathrm{H}, \mathrm{Al}$-qudah $\mathrm{M}$, et al. Antimicrobial activity of crude extract of some plant leaves. Research Journal of microbiology. 2012;7(1):59-67. https://doi.org.10.3923/jm.2012.59.67

38. Hussain A, Khan MN, Iqbal Z, Sajid MS, Khan MK. Anthelmintic activity of Trianthema portulacastrum L. and Musa paradisiaca L. against gastrointestinal nematodes of sheep. Veterinary Parasitology. 2011;179(1-3):92-99. https:// doi.org/10.1016/j.vetpar.2011.02.022

39. Kavitha D, Parvatham R, Padma PR. Assessment of Trianthema portulacastrum for its antimicrobial potential and investigation of their phytochemicals using HPTLC, GC-MS, and IR. International Journal of Pharmacy and Pharmaceutical Sciences.2013;6(1):675-86.

40. Banerji A, Chintalwar GJ, Joshi NK, Chadha MS. Isolation of ecdysterone from Indian plants. Phytochemistry. 1971;10(9):2225-26. https://doi.org/10.1016/S0031 $\underline{9422(00) 97227-3}$

41. Karim MS, Ashraf N, Kalam A, jahan N, Jafri MA, Ahmad G Effects of Biskhapra (Trianthema portulacastrum Linn.) leaves extract in adriamycin induced nephritic syndrome. Intl J Gr Pharm. 2011. https://doi.org/10.4103/0973$\underline{8258.94357}$

42. Laupland KB. Fever in the critically ill medical patient. Critical Care Medicine. 2009;37(7):S273-78. https://doi.org/10.1097/CCM.0b013e3181aa6117

43. Yamaki J, Nagulapalli Venkata KC, Mandal A Bhattacharyya P, Bishayee A. Health-promoting and disease-preventive potential of Trianthema portulacastrum Linn. (Gadabani) - An Indian medicinal and dietary plant. Journal of Integrative Medicine. 2008;14(2):84-99. https://doi.org/10.1016/S2095-4964(16)60247-9

44. Yaqoob S, Bushra S, Muhammad M. In vitro antioxidant activities of Trianthema portulacastrum L. hydrolysates. Prev Nutr Food Sci. 2014;19(1):27-33. https://doi.org/10.3746/pnf.2014.19.1.027

45. Liou GY, Storz P. Reactive oxygen species in cancer. Free Radical Research. 2010;44(5):479-96. https://doi.org/10.3109/10715761003667554

46. Asif M, Atif M, Malik ASA, Dan ZC, Ahmad I, Ahmad A. Diuretic activity of Trianthema portulacastrum crude extract in albino rats. Tropical Journal of Pharmaceutical Research.

http://dx.doi.org/10.4314/tjpr.v12i1.15

47. Mandal A, Bishayee A, Chatterjee M. Trianthema portulacastrum affords antihepatotoxic activity against carbon tetrachloride-induced chronic liver damage in mice: Reflection in subcellular levels. Phytotherapy Research. 1997;216-21. https://doi.org/10.1002/(SICI)10991573(199705)11:3<216::AID-PTR74>3.0.CO;2-L

48. Boyd EM, Bereczky GM. Liver necrosis from paracetamol British Journal of Pharmacology and Chemotheapy. 1996;26(3):604-14.

https://doi.org/10.1111/j.1476-5381.1996.tb01841.X

49. Davidson DGD, Easthan WN. Acute liver necrosis following overdose of paracetamol. British Medical Journal. 1966 2(5512):497-79. https://doi.org/10.1136/bmj.2.5512.497

50. Mandal A, Bishayee A. Trianthema portulacastrum Linn Display anti-inflammatory responses during chemically induced rat mammary tumorigenesis through simultaneous and differential regulation of NK-kB and Nrf2 signalling pathways. International Journal of 
Molecular Sciences. 2015;16(2):2426-45. https://doi.org/10.3390/ijms16022426

51. Geethalakshmi R, Sarada, DVL, Ramasamy K. Trianthema decandra L: A review on its phytochemical and pharmacological profile. Int J Engg Sci Tech. 2010;2(5):97679.

52. Bharathidhasan S, Babu G, Balakrishnan V. In vitro evaluation of the nutritive value of Trianthema portulacastrum as a source of fodder for ruminants. Malaysian Journal of Nutrition. 2007;13(2):179-87.

53. Khare CP. Indian Medicinal Plants, an Illustrated Dictionary. Berlin/Heidelberg: Springer Verlag, 2006; p.96.

54. Khan N, Sultana A, Tahir N, Jamila N. Nutritional composition, vitamins, minerals and toxic heavy metals analysis of Trianthema portulacastrum L., a wild edible plant from Peshawar, Khyber Pakhtunkhwa, Pakistan.
African Journal of Biotechnology. 2013;12(42):6079-85. https://doi.org/10.5897/AJB2013.12972

55. Shivhare MK, Singour PK, Chaurasiya PK, Pawar RS Trianthema portulacastrum Linn. (bishkhapra). Pharmacognosy Reviews. 2012;6(12):132-40. https://doi.org10.4103/0973-7847.99947

56. Ara A, Akram A, Ajmal M, Akhund S, Nayyar BG. Pharmacological, nutritional and allelopathic attributes of noxious weed, Trianthema portulacastrum L. (Horse purslane). Pure and Applied Biology. 2015;4(3):340-52. https://dx.doi.org/10.19045/bspab.2015.43010

57. Bhattacharya S, Chatterjee M. Protective role of Trianthema portulacastrum against diethylnitrosoamineinduced experimental hepatocarcinogenesis. Cancer Letters. 1998;129(1):7-13. 